\title{
KAJIAN CULTURAL LAG DALAM KEHIDUPAN MASYARAKAT PERKAMPUNGAN BUDAYA BETAWI SETU BABAKAN PADA ERA GLOBALISASI
}

\author{
Aulia Nursyifa \\ Fakultas Keguruan dan Ilmu Pendidikan, Universitas Pamulang \\ aulianursyifa220806@gmail.com \\ Naskah diterima: 12 Februari 2018, review: 1 Maret 2018, revisi: 2 Maret 2018, \\ disetujui: 7 Maret 2018.
}

\begin{abstract}
This research aims to know the shape of cultural lag in the community of the Betawi Setu Babakan Village after the Ghetto culture of Engineering results the Government of DKI Jakarta. The method that used in this study is qualitative method. The research results showed that the Government of DKI Jakarta is trying to build a facility there are various means for protection of the Betawi in the era of globalization, but in practice local community contradictions occur less empowered, the community does not have the mental preparedness for menyeimbangi development that the more progressive so that experiencing a failed. Based on the theory of cultural lag of Ogburn, researchers sought to expose the failed, therefore needs to be an attempt to overcome the Cultural communities failed Betawi Setu Babakan by changing mindsets of society so that in accordance with the Master Plan of development of the Betawi Setu Babakan Village.
\end{abstract}

Keywords: cultural lag, Betawi society, globalization

\author{
Jurnal Pendidikan Kewarganegaraan \\ Journal of Civics and Education Studies \\ The journal is published by Department of Civic Education \\ Faculty of Teacher Training and Education \\ Universitas Pamulang - Indonesia
}

Copyright $\odot 2018$ |ISSN: 2302-0865 


\section{PENDAHULUAN}

Pembangunan kota Jakarta yang sangat pesat menjadikan kota Jakarta sebagai kota megapolitan, tidak hanya menjadi pusat ekonomi dan pusat pemerintahan bangsa Indonesia tetapi juga sebagai pusat berkumpulnya budaya bangsa. Jakarta tidak hanya menjadi magnet bagi mereka yang ingin mengadu nasib di ibukota dari seluruh pelosok negeri tetapi juga menjadi pintu gerbang masuknya arus globalisasi dunia. Menurut Mubah (2011), "globalisasi menjadi sebuah fenomena yang tak terelakkan, globalisasi berpengaruh buruk pada pudarnya eksistensi budaya-budaya lokal". Oleh karena itu, budaya-budaya lokal bangsa Indonesia harus dilestarikan agar tidak punah dalam perkembangan zaman. Bagaikan dua mata koin yang yang berbeda, disatu sisi melihat kemajuan kota Jakarta yang sangat berkembang pesat dilihat dari pembangunan fisik gedung-gedung pencakar langit yang menjulang tinggi, ternyata disisi lain terjadi kontradiksi dengan kehidupan masyarakat ibukota yang semakin terpuruk khususnya kehidupan masyarakat asli ibukota yang semakin terpinggirkan akibat tergusurnya "kantong-kantong budaya" yang merupakan kampungnya orang Betawi di Jakarta, sebagaimana pendapat Chaer (2015: v) “setelah era 1950-an terjadi pembongkaran kampung-kampung orang Betawi untuk keperluan perluasan kota Jakarta dan penyediaan pemukimanpemukiman baru pendatang, pembongkaran kebun orang Betawi”. Hal itu selaras dengan apa yang diungkapkan oleh Steinberg (2007: 355), “Jakarta merupakan kota metropolitan meltingpot yang terdiri dari banyak budaya imigran Indonesia, meskipun berbagai upaya terus menerus dilakukan Jakarta sebagai kotanya orang-orang Betawi asli, namun yang terjadi identitas budaya Betawi justru semakin pudar". Jika hal ini terus dibiarkan maka lama kelamaan orang Betawi akan kehilangan identitasnya karena tidak ada lagi di kota Jakarta, orang Betawi penduduk asli Jakarta yang ada saat ini hanya tinggal sejarah.

Keberadaan budaya Betawi menurut Moechtar (2012: 135), "budaya Betawi mengalami kemunduran, mengingat semakin besar arus urbanisasi serta pembangunan kota tanpa berlandaskan wawasan lingkungan dan budaya yang terjadi di DKI Jakarta". Sejak pemerintahan Gubernur Ali Sadikin telah ditetapkan Condet sebagai cagar budaya Betawi, namun menurut Marzali (2009:70) “Condet pada tahun 1982 telah berubah menjadi tempat bermukim penduduk yang bekerja di ibukota, sehingga terjadi perubahan sosial dan lingkungan alam di kawasan Condet". Akhirnya Condet dianggap telah gagal sebagai Cagar Budaya Betawi akibat masuknya arus modernisasi ke ibukota ditambah lagi dengan keberadaan kaum pendatang ke daerah tersebut. Kegagalan Condet menjadi pelajaran yang sangat berharga bagi masyarakat Betawi yang sangat menginginkan kampung Betawi. Oleh karena itu, sebagai upaya untuk melestarikan budaya lokal asli kota Jakarta Pemerintah Provinsi DKI Jakarta 
melakukan rekacipta dengan adanya Perkampungan Budaya Betawi Setu Babakan, tempat ini juga dijadikan sebagai wadah menyatukan orang-orang Betawi yang sudah terpencar di berbagai daerah, dan sebagai tempat wisata edukatif untuk masyarakat seperti wisata budaya, wisata agro, dan wisata air.

Sejak ditetapkannya kampung Setu Babakan sebagai Perkampungan Budaya Betawi disambut baik oleh masyarakat, segala bentuk pendukungan terhadap Perkampungan Budaya Betawi Setu Babakan dikerahkan oleh berbagai kalangan termasuk masyarakat sekitar agar terwujud apa yang telah direncanakan bersama sesuai dengan master plan.Berdasarkan Peraturan Daerah Nomor 3 tahun 2005 dalam pasal I tentang Penetapan Perkampungan Budaya Betawi di Kelurahan Srengseng Sawah Kecamatan Jagakarsa Kotamadya Jakarta Selatan yaitu:

Perkampungan Budaya Betawi adalah suatu kawasan di Jakarta dengan komunitas yang ditumbuhkembangkan budaya Betawi yang meliputi seluruh hasil gagasan dan karya baik fisik maupun nonfisik yaitu kesenian, adat istiadat, folklore kesastraan dan kebahasaan, kesejarahan serta bangunan yang bercirikan keBetawian.

Berbagai bentuk pembangunan baik fisik maupun nonfisik dilakukan dan akhirnya merubah wajah kampung Setu Babakan menjadi kampung wisata yang lengkap dengan sarana dan fasilitas yang ada. Tidak cukup pembangunan fisik saja yang dibutuhkan tetapi juga yang harus diperhatikan dalam pembangunan nonfisik. Pembangunan nonfisik berarti membangun masyarakat untuk lebih baik lagi selaras dengan pembangunan fisik yang ada. Namun sayangnya pembangunan fisik Perkampungan Budaya Betawi Setu Babakan lebih menonjol dibandingkan dengan pembangunan nonfisik sehingga menyebabkan masyarakatnya semakin tertinggal jauh dari pembangunan yang ada. Hal tersebut menjadi permasalahan pelik yang harus dihadapai oleh pihak pengelola Perkampungan Budaya Betawi Setu Babakan. Selaras dengan pendapat informan sebagai berikut:

Konsep dari pembangunan Perkampungan Budaya Betawi Setu Babakan sebenarnya yaitu pembangunan fisik yang ada harus seimbang dengan pembangunan nonfisik, tetapi kenyataannya SDM masyarakat kita masih mengalami ketertinggalan jika dibandingkan pembangunan fisik yang ada. Maka langkah yang harus dilakukan perlu mengejar ketertinggalan tersebut (Petikan wawancara dengan narasumber IS, pada 4 Oktober 2016).

Berdasarkan hasil wawancara tersebut, peneliti tertarik melakukan penelitian berdasarkan permasalahan tentang masalah ketertinggalan yang terjadi pada masyarakat Perkampungan Budaya Betawi Setu Babakan. Kajian teori ketertinggalan budaya pada masyarakat Perkampungan Budaya Betawi Setu Babakan bersumber dari teori cultural lag 
dari William F. Ogburn. Menurut Setiadi dan Kolip (2011: 143) "teori ketertinggalan budaya artinya perkembangan sosiokultural tidak selalu sama cepatnya dengan sikap mental masyarakat, sikap masyarakat belum siap secara mental dalam mengikuti perubahan". Oleh sebab itu, perlu adanya langkah nyata dalam mempersiapkan kesiapan mental masyarakat dalam menerima berbagai perubahan pada masyarakat Perkampungan Budaya Betawi Setu Babakan.

Berdasarkan permasalahan di atas peneliti berupaya untuk menjawab pertanyaan ketertinggalan apa yang terjadi pada masyarakat Perkampungan Budaya Betawi Setu Babakan? mengapa masyarakat mengalami ketertinggalan padahal Pemprovinsi DKI Jakarta sangat berkontribusi besar terhadap kemajuan budaya lokal dikampung mereka dan bagaimana upaya untuk mengejar ketertinggalan tersebut?. Melalui penelitian ini, peneliti merasa sangat tertarik untukmengetahuinya lebihlanjut mengenai ketertinggalan budaya pada masyarakat Perkampungan Budaya Betawi Setu Babakan.

\section{METODE PENELITIAN}

Penelitian ini menggunakan metode penelitian kualitatif. Pemilihan metode kualitatif bertujuan untuk lebih memudahkan peneliti dalam mendeskripsikan dan menganalisis berbagai fenomena yang terjadi tentang cultural lag yang terjadi pada masyarakat Setu Babakan. Moleong (2012:6) menjelaskan bahwa "penelitian kualitatif bermaksud untuk memahami fenomena tentang apa yang dialami oleh subjek penelitian misalnya perilaku, persepsi, motivasi, tindakan dan lain-lain." Dengan memperhatikan paparan di atas, peneliti menganggap bahwa metode penelitian kualitatif paling tepat dijadikan metode penelitian mengenai cultural lag pada masyarakat Betawi Setu Babakan karena penelitian ini menggambarkan secara deskriptif tentang fenomena perubahan dalam kehidupan masyarakat Setu Babakan setelah dijadikan Perkampungan Budaya Betawi. Peneliti berperan secara partisipatif di tengah-tengah masyarakat Perkampungan Budaya Betawi Setu Babakan dengan berbagai aktifitas, mengamati perilaku masyarakat, berinteraksi dengan warga sekitar, dan memahami makna dari berbagai fenomena yang terjadi dalam kehidupan masyarakat tentang pemahaman mereka terhadap dunia sekitarnya.

Penelitian dilaksanakan di kawasan Setu Babakan yang termasuk kedalam wilayah Perkampungan Budaya Betawi Setu BabakanRW.08 Kelurahan Srengseng Sawah, Kecamatan Jagakarsa, Kotamadya Jakarta Selatan, DKI Jakarta. Pemilihan tempat penelitian di Setu Babakan karena kawasan ini menjadi sangat menarik untuk diteliti karena tempat tersebut merupakan kawasan yang telah ditetapkan oleh Pemerintah Propinsi DKI Jakarta sebagai salah satu role model Perkampungan Budaya Betawi yang dianggap masih kuat menjaga nilai-nilai serta tradisi para leluhur budaya Betawi sampai dengan saat ini masih dipegang 
teguh serta dipraktekkan dalam kehidupan sehari-hari.

Dalam melakukan penelitian tentang cultural lag masyarakat Betawi Setu Babakan ini, peneliti membagi informan penelitian kedalam beberapa bagian yaitu informan kunci dan informan pendukung. Menurut Alwasilah (2015: 111) "informan kunci (key informants) merupakan petunjuk bagi peneliti karena dia menguasai teritori penelitian". Terdapat 7 informan kunci diantaranya tokoh masyarakat Betawi dan masyarakat Betawi yang ada di Perkampungan Budaya Betawi Setu Babakan. Sedangkan informan pendukung terdiri dari 7 informan misalnya pihak pengelola, masyarakat pendatang, dan tokoh seniman Betawi di Perkampungan Budaya Betawi Setu Babakan.

Peneliti melakukan triangulasi untuk memeriksa kebenaran data yang peneliti dapatkan dari lokasi penelitian mengenai cultural lag masyarakat Betawi Setu Babakan dengan membandingkan berbagai data yang diperoleh dari berbagai sumber diantaranya hasil observasi, wawancara mendalam, dan dokumentasi. Sebagaimana pendapat Creswell (2014: 286) "strategi validitas dengan melakukan triangulasi (triangulate) dari sumbersumber data yang berbeda dengan memeriksa bukti-bukti yang berasal dari sumber-sumber tersebut".Observasi dilakukan untuk melihat gambaran cultural lag masyarakat Setu Babakan. Wawancara dilakukan untuk mengetahui berbagai opini, persepsi, penilaian masyarakat Setu Babakan mengenai cultural lag yang mereka alami sejak adanya Perkampungan Budaya Betawi.
Sedangkan dokumentasi dilakukan untuk bukti otentik penelitian dalam bentuk foto selain itu juga dalam bentuk berbagai dokumen penting yang mendukung penelitian cultural lag pada masyarakat Betawi ini.

Proses analisis data yang peneliti gunakan yaitu analisis kualitatif dan menggunakan metode deskriptif analitik. Menurut Miles dan Huberman (dalam Silalahi, 2010: 339) "kegiatan analisis terdiri dari tiga alur kegiatan yang terjadi secara bersamaan yaitu reduksi data, penyajian data, dan penarikan kesimpulan atau verifikasi". Melalui proses analisis kualitatif, peneliti dapat menggambarkan bagaimana cultural lag masyarakat Betawi Setu Babakan yang terjadi pada era globalisasi.

\section{HASIL DAN PEMBAHASAN}

Pembangunan di Perkampungan Budaya Betawi Setu Babakan tidak cukup hanya membangun fisik saja, namun yang perlu diperhatikan adalah pembangunan nonfisiknya. Pembangunan nonfisik berarti membangun masyarakat untuk lebih baik lagi, agar selalu selaras dengan pembangunan fisik yang semakin progresif. Namun sayangnya pembangunan fisik Perkampungan Budaya Betawi Setu Babakan lebih menonjol dibandingkan dengan pembangunan nonfisik, sehingga menyebabkan pembangunan masyarakat semakin tertinggal jauh dari apa yang direncanakan. Sebagaimana pendapat Soekanto (2010:298) “mengenai arti ketertinggalan yaitu suatu keadaan 
tertinggalnya suatu unsur tertentu terhadap unsur lainnya yang erat hubungannya". Selaras dengan pendapat Hatu (2011: 5) "cultural lag merupakan suatu kondisi dimana kebudayaan material mengalami perubahan, sementara kebudayaan nonmaterial lebih lambat dalam proses penyesuaian". Jadi yang dikatakan cultural lag terjadi jika unsur-unsur kehidupan masyarakatnya tertinggal jauh dengan berbagai pembangunan sarana dan fasilitas fisik yang berkembang semakin pesat, sehingga harus ada penyesuaian terhadap perubahan yang ada. Pada awal pembangunan Perkampungan Setu Babakan tahun 2000 dibangun kawasan zona embrio meliputi pintu gerbang $\mathrm{Si}$ Pitung, 3 rumah tradisional Betawi (yang dijadikan sebagai kantor pengelola, wisma Betawi, dan galeri Betawi), langgar atau musola, panggung teater, lahan parkir, Pemerintah Provinsi DKI Jakarta turut andil dalam merenovasi rumahrumah warga diarea Perkampungan Budaya Betawi Setu Babakan serta warung-warung direnovasi bernuansa Betawi. Berikut ini salah satu rumah khas Betawi yang ada di perkampungan ini.

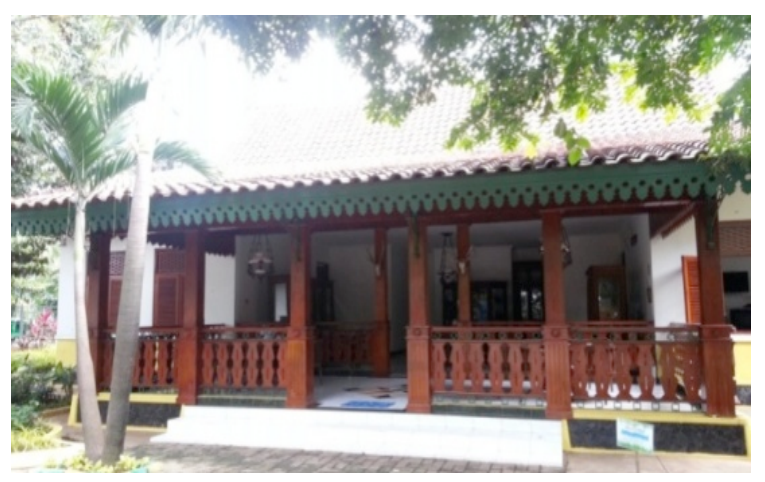

Gambar 1. Rumah Khas Betawi (Sumber: Dokumentasi Peneliti) $\begin{array}{cccr}\text { Selanjutnya } & \text { pada } & \text { tahun } & 2016 \\ \text { pembangunan } & \text { zona } & \text { A } & \text { selesai }\end{array}$ dirampungkan, zona A menjadi miniatur kampung Betawi yang sangat lengkap dengan fasilitas lengkap meliputi rumah kebaya, wisma Betawi, pusat pendidikan dan pelatihan seni budaya, museum sejarah, gedung kesenian dan serbaguna, Amphitheater dan 6 bangunan rumah adat, rumah pesisir, musolah, rumah jaga, rumah genset, toilet umum, pintu gerbang, saung atau gajebo, parkir, dermaga, kebun buah, dan sebagainya. Zona A menjadi icon Perkampungan Budaya Betawi Setu Babakan yang dibangun dengan sangat megah berornamen modern dan tidak meninggalkan ciri khas tradisional Betawinya, namun sayangnya perkampungan ini tidak ada penghuninya hanya sebatas bangunan tanpa adanya masyarakat yang mendiami. Meskipun berbagai fasilitas tersebut tidak sepenuhnya dapat digunakan pada saat ini, zona A sudah dibuka untuk umum. Berikut ini penampakkan dari zona $\mathrm{A}$ Perkampungan Budaya Betawi Setu Babakan.Berikut gambaran pembangunan zona A.

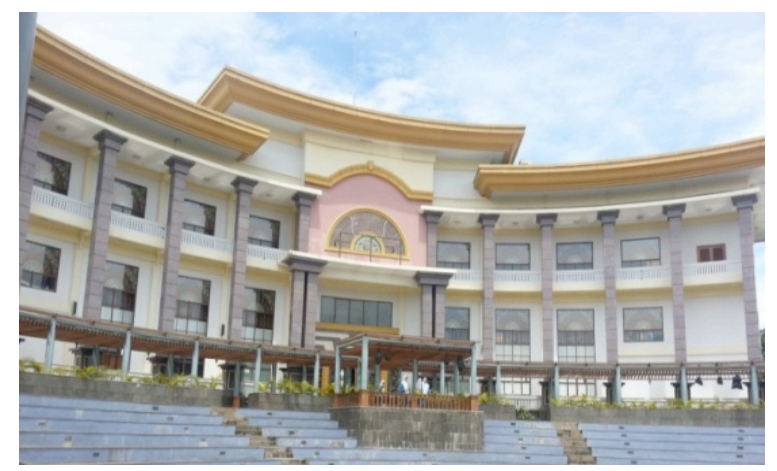

Gambar 2. Zona A (Sumber: Dokumentasi Peneliti) 
Tidak seperti pembangunan fisiknya, justru pembangunan nonfisik pada kenyataanya sampai saat ini memang masih jauh tertinggal dari apa yang diharapkan. Tidak semudah membalikan telapak tangan untuk merubah keadaan masyarakat agar sesuai dengan apa yang diinginkan oleh Pemprov DKI Jakarta. Menurut Brinkman (2006: 1014) "budaya nonmaterial cenderung tertinggal budaya materiil karena masih ada masyarakat yang masih berpegang teguh pada bentukbentuk lama untuk berbagai alasan misalnya kebiasaan sosial, takut pengucilan, dan kekuatan tradisi dan elit, serta banyak lagi lainnya”. Aspek budaya nonmaterial dapat menjadi hambatan untuk berubah dan tertinggal dari budaya material, ketidakmampuan mengarah kepada permasalahan sosial seperti pegangguran, kriminalitas, penyimpangan sosial, dan sebagainya.

Pada awal pembangun Perkampungan Budaya Betawi Setu Babakan, masyarakat setempat sangat antusias berkontribusi secara langsung dalam berbagai kegiatan seperti kesenian, perekonomian, dan kegiatan masyarakat Betawi di Perkampungan Budaya Betawi Setu Babakan, tidak hanya itu masyarakat juga berpartisipasi dalam mengawal pembangunan Perkampungan Budaya Betawi Setu Babakan. Sebagaimana yang dikatakan oleh narasumber yaitu:

Eforia budaya sangat tinggi ketika ditahun-tahun awal berdirinya Perkampungan Budaya Betawi Setu Babakan, masyarakat sangat antusias dalam membangun Perkampungan Budaya Betawi
Setu Babakan. Lama kelamaan antusias masyarakat turun, kita memikirkan budaya saja tidak akan cukup saat masyarakat berfikirnya hanya soal perut karena budaya itu no profit yang harus ditekankan dengan adanya budaya membuat masyarakat semakin beradab (Petikan wawancara dengan SS, pada 4 Oktober 2016).

Seyogyanya masyarakat sekitar diharapkan untuk menerima berbagai pembaharuan di kampung mereka, baik dari segi fisik maupun nonfisik tanpa menghilangkan esensi dari budaya Betawi yang mereka pegang teguh sejak dahulu dan tanpa adanya unsur paksaan dari pihak manapun untuk mempertahankan eksistensi budaya mereka. Adanya Perkampungan Budaya Betawi Setu Babakan menyadarkan masyarakat agar pentingnya mencintai budaya bangsa hingga mewariskan ke anak cucu mereka sehingga menumbuhkan rasa memiliki akan budaya yang mereka junjung tinggi selama ini. Namun belakangan ini perilaku masyarakat yang mengalami ketertinggalan menjadi kekhawatiran semua pihak, apa yang sebenarnya terjadi pada masyarakat Perkampungan Budaya Betawi Setu Babakan saat ini menjadi cambuk bagi Pemprov DKI Jakarta maupun pihak pengelola Perkampungan Budaya Betawi Setu Babakan untuk melakukan evaluasi dalam pembangunan masyarakat Perkampungan Budaya Betawi Setu Babakan untuk lebih baik lagi.

Pembangunan fisik dapat saja diselesaikan dengan singkat dengan dana 
yang besar, namun membangun masyarakat memerlukan waktu yang panjang dan membutuhkan pembiasaan merubah mindset dan perilaku yang sudah mengakar. Pada awalnya masyarakat Perkampungan Budaya Betawi Setu Babakan mereka mau dibina, diberikan pelatihan, diberikan berbagai pendidikan keterampilan, dan sebagainya. Tetapi tidak ada yang dapat menjamin masyarakat untuk selalu konsisten dengan perubahan yang diinginkan. Sebagaimana yang diungkapkan oleh pengelola sebagai berikut.

Perubahan masyarakat

merupakan suatu hal yang pasti. Perubahan masyarakat tidak akan pernah selesai jika hanya sematamata membangun fisiknya saja. Perubahan dalam kehidupan masyarakat menjadi suatu kekhawatiran, sehingga kita harus mengetahui apa yang menjadi formulanya. Budaya itu tidak ada polisinya sehingga ketika hari ini masyarakat berpikir sangat kuat budaya Betawinya, lantas bagaimana dengan esok, lusa, atau waktu yang akan datang bisa saja berubah (Petikan wawancara dengan SS, pada 4 Oktober 2016).

Berdasarkan pernyataan di atas, maka dapat disimpulkan bahwa membangun masyarakat bukanlah hal yang mudah untuk dilakukan karena butuh penyesuaian diri dengan keadaan di Perkampungan Budaya Betawi Setu Babakan. Konsep dari pembangunan Perkampungan Budaya Betawi Setu Babakan yaitu pembangunan fisik harus seimbang dengan pembangunan nonfisik, jangan sampai pembangunan fisik yang maju tetapi masyarakatnya mengalami ketertinggalan. Pihak pengelola pun telah mengakui akan ketertinggalan masyarakat sekitar Perkampungan Budaya Betawi Setu Babakan jika dibandingkan pembangunan fisik yang ada. Hal tersebut menjadi permasalahan pelik yang harus dihadapai oleh Pemprov DKI Jakarta dan pihak pengelola Perkampungan Budaya Betawi Setu Babakan dalam merubah mindset masyarakat agar selalu selaras dengan pembangunan.

Diawal pembangunan memang semua berjalan baik-baik saja sesuai rencana, namun seiring perjalanan terdapat suatu masa ketika masyarakat merasa telah jenuh sehingga partisipasi masyarakat di Perkampungan Budaya Betawi Setu Babakan saat ini telah menurun. Hal ini selaras dengan penelitian Hidayat (2015: 18) yang menenemukan bahwa masyarakat desa wisata saat ini mengalami perubahan yang dapat dilihat dari tingkat partisipasi masyarakat di desa wisata semakin menurun dan organisasi masyarakat mulai ditinggalkan. Berdasarkan penelitian tersebut dapat disimpulkan tidak hanya di Perkampungan Setu Babakan saja yang mengalami perubahan, di tempat wisata lainnya pun mulai mengalami perubahan disaat masyarakat mulai mengalami penurunan partisipasi mereka dalam pembangunan kawasan wisata. Penurunan partisipasi masyarakat dalam pembangunan Perkampungan Budaya Betawi Setu Babakan karena masyarakat beranggapan bahwa mereka tidak diperhatikan lagi oleh pihak pengelola 
maupun pemerintah daerah setempat, apalagi sejak berbagai otoritas maupun kebijakan diambil alih langsung oleh Pemprov DKI Jakarta semua kebijakan bersifat top down yang berasal dari pusat tanpa melibatkan masyarakat secara langsung dalam pengambilan keputusan, hal itu sangat berbeda dengan komitmen di awal pembangunan Perkampungan Budaya Betawi Setu Babakan.

Pemprov mempunyai wewenang yang besar dalam pembangunan ini sehingga masyarakat diharapkan mengikuti segala aturan-aturan yang ada. Dapat disimpulkan bahwa kekuatan elit sangat besar sehingga dapat memberikan dampak negatif yang dirasakan masyarakat jika tidak memberikan keadilan atau keuntungan bagi masyarakat. Ibarat dua sisi mata koin yang berbeda, Pemprov dianggap tidak melibatkan masyarakat dalam membuat kebijakan namun disisi lain jika tidak adanya peran Pemprov maka tidak ada pembangunan di Perkampungan Budaya Betawi Setu Babakan hingga saat ini.

Peran pemerintah sangat besar terhadap Perkampungan Budaya Betawi Setu Babakan, jika pemerintah meninggalkan Perkampungan Budaya Betawi Setu Babakan maka tidak akan ada pembangunan lagi di Perkampungan Budaya Betawi Setu Babakan. Kita perlu belajar dengan penelitian yang dilakukan oleh Waha (2016: 17) yang menemukan bahwa menurunnya objek wisata disebabkan karena nilai sosial masyarakat yang semakin menurun, pemerintah mulai malas dan mulai tidak peduli untuk mengelola objek wisata tersebut.
Ketika Pemprov tidak lagi membiayai Perkampungan Budaya Betawi Setu Babakan maka tinggal menunggu kehancuran dari kampung Betawi ini, tentunya kegagalan yang dialami oleh Condet menjadi pelajaran yang paling berharga untuk Perkampungan Budaya Betawi Setu Babakan. Walaupun Pemprov sudah berganti-ganti kepemimpinan tetapi pembangunan Perkampungan Budaya Betawi Setu Babakan tetap berjalan sampai saat ini. Apreasiasi yang sangat besar terhadap Pemprov DKI Jakarta yang sampai saat ini masih konsisten melestarikan budaya Betawi di Perkampungan Budaya Betawi Setu Babakan, seharusnya fasilitas dari Pemprov dapat dimanfaatkan oleh masyarakat sekitar dengan optimal karena sayang rasanya jika diabaikan begitu saja, padahal ditempat yang berbeda banyak objek wisata budaya yang kurang perhatian pemerintah daerahnya.

Salah satu faktor penyebab terjadi ketertinggalan yaitu ketika masyarakat mengkaitkan faktor ekonomi menjadi patokan dalam berbudaya, pergeseran pemikiran tersebut menjadi permasalahan pelik sehingga menyebabkan masyarakat menjadi acuh dengan budayanya dan menganggap bahwa budaya hanya untuk dikomersialkan. Hal itu selaras dengan penelitian Parwitaningsih (2003: 106) yang menemukan bahwa identitas orang Betawi mengalami perubahan seiring dengan perubahan orang Jakarta yaitu pertimbangan ekonomi sebagai landasan untuk bertindak. Jadi mereka yang memiliki kepentingan ekonomi akan giat berada di Perkampungan Budaya Betawi 
Setu Babakan landasan mereka berbudaya karena kepentingan komersil, tetapi bagi mereka yang tidak memiliki kepentingan apa-apa di Perkampungan Budaya Betawi Setu Babakan bertindak pasif bahkan merasa bahwa Perkampungan Budaya Betawi Setu Babakan tidak memberikan manfaat apa-apa bagi kehidupan mereka. Memang sulit menuntut masyarakat untuk idealis terhadap budayanya memang sulit karena tidak semua orang memiliki loyalitas yang tinggi terhadap budayanya tanpa memikirkan hal lainnya. Namun jika hal tersebut terus dibiarkan maka ketertinggalan pola-pola hidup masyarakat akan menjadi permasalahan yang harus dipecahkan.

Jika dahulu masyarakat dianjurkan untuk menjadikan rumah mereka menjadi rumah yang bernuansa Betawi bahkan Pemprov DKI Jakarta membiayai renovasi rumah tersebut, namun sayangnya proyek tersebut hanya diawal pembangunan Perkampungan Budaya Betawi Setu Babakan saja, setelah itu banyak rumah Betawi yang tidak terawat lagi bahkan banyak yang dijadikan rumah kontrakan dan saat ini terdapat rumah kaum pendatang dengan nuansa modern tanpa ada unsur Betawinya padahal mereka berada di lingkungan kampung Betawi. Saat ini ada pergeseran pola pikir masyarakat karena mereka lebih mementingkan kebutuhan ekonomi, sehingga menjual tanah mereka untuk dijadikan perumahan modern yang jauh dari unsur Betawinya, dari pada harus menjual kepada Pemprov DKI Jakarta yang mereka anggap ditawar murah untuk perluasan Perkampungan Budaya Betawi
Setu Babakan. Selaras dengan pendapat Wardiningsih (2005: 115) yaitu "terjadi perubahan lahan dan kawasan di Perkampungan Budaya Betawi Setu Babakan akibat kebijakan yang belum berjalan sesuai dengan peraturan yang telah ditetapkan dan desakan kebutuhan ekonomi masyarakat serta kebutuhan akan tempat tinggal".

Hal ini menjadi kekhawatiran Pemprov DKI Jakarta jika masyarakat lebih tergiur dengan materi sehingga kampung budaya yang ada tinggal bangunan saja, sedangkan masyarakatnya pindah ke pinggiran kota Jakarta. Sebagaimana yang diungkapkan oleh Oktaviyanti (2013: 207) yaitu "terdapat dampak perubahan sosial budaya akibat adanya interaksi wisatawan dengan masyarakat lokal di kawasan wisata diantaranya sifat materialis masyarakat setempat dan adanya perubahan budaya dalam pertunjukkan seni". Jika mindset masyarakat hanya pada profit belaka maka tidak menutup kemungkinan budaya tidak lagi dipandang sebagai bagian dari hidup yang patut untuk dipertahankan namun tidak lebih hanya sebatas hiburan.

Pemberdayaan masyarakat dalam seni budaya Betawi yang ada saat ini sangat memprihatinkan karena semangat berbudaya tidak seperti diawal pembangunan, jika dahulu masyarakat berbondong-bondong membentuk sanggar seni Betawi seperti tari topeng, ondelondel, tanjidor, dan sebagainya semua berasal dari inisiatif masyarakat setempat. Lama kelamaan seni Betawi mati suri 
karena tidak regenerasi dari generasi muda untuk melestarikan budaya Betawi.

Begitupun dengan pemberdayaan membatik Betawi yang tidak diminati oleh masyarakat sekitar. Pihak pengelola telah melakukan berbagai cara agar masyarakat setempat mau membatik Betawi dengan mengundang para ibu-ibu rumah tangga, dan juga mengajak para pemuda di sekitar Perkampungan Budaya Betawi Setu Babakan untuk melestarikan batik Betawi. Namun hanya bertahan beberapa kali pertemuan mereka tidak datang lagi dengan alasan sibuk mengurus anak, sibuk memasak, tidak ada waktu, bosan, tidak menghasilkan uang yang banyak, tidak telaten membuat batik, masyarakat inginnya instan lebih baik menjual langsung batik yang sudah jadi dari pada harus membuat sendiri, para pemuda lebih memilih bekerja di kota dengan penghasilan yang tinggi dari pada mengharapkan dari hasil membatik, dan berbagai alasan lainnya.

Padahal jika masyarakat sekitar terutama pemuda dapat memanfaatkan sumber daya yang ada maka akan menghapus tingkat pengangguran dengan membuka lapangan kerja baru di sektor wisata salah satunya dengan hasil membatik. Jika bukan masyarakat setempat yang berperan di kampung mereka sendiri, maka akan di khawatirkan lama kelamaan justru masyarakat pendatang yang akan maju di kampung Betawi terbukti dengan adanya pendatang yang justru menjadi pembatik Betawi di Perkampungan Budaya Betawi Setu Babakan.
Ada juga permasalahan pembangunan nonfisik yang dirasakan yaitu sangat rendahnya keterlibatan masyarakat sekitar menjadi tenaga kerja di Perkampungan Budaya Betawi Setu Babakan karena mayoritas masyarakat yang bekerja hanya menduduki posisi yang rendah seperti menjadi petugas parkir, petugas pembersih Setu Babakan, petugas kebersihan, penjaga pintu masuk yang meminta karcis masuk ke Perkampungan Budaya Betawi Setu Babakan, penjaga keamanan, dan sebagainya. Sedangkan warga yang berkerja diruang kantor sangat jarang sekali.

Keterbatasan pendidikan dan pengetahuan masyarakat Perkampungan Budaya Betawi Setu Babakan menjadi penyebab masyarakat tidak bisa menjadi pegawai di Perkampungan Budaya Betawi Setu Babakan. Apalagi rekrutmen menggunakan jalur Pegawai Negeri Sipil atau melalui mekanisme Pemda sehingga masyarakat merasa kesulitan menjadi pegawai di Perkampungan Budaya Betawi Setu Babakan, sehingga muncul sebuah stigma di masyarakat hanya orang luar saja yang bisa menjadi pegawai padahal mereka tidak mengerti tentang selak beluk daerah ini, sedangkan penduduk asli dilupakan maka hal ini tidak sesuai dengan janji diawal pembangunan yang dapat menyerap tenaga kerja banyak dari masyarakat sekitar.

Di samping itu, pembangunan fisik Perkampungan Budaya Betawi Setu Babakan yang belum mencapai 100\% membuat pihak pengelola belum membuka lowongan pekerjaan bagi masyarakat sekitar. Berdasarkan hasil 
penelitian banyak masyarakat Betawi khususnya para pemuda sekitar yang hanya duduk di pinggiran Setu Babakan, padahal mereka dapat diberdayakan. Ada juga diantara mereka yang bekerja misalnya menjadi petugas parkir atau di area wisata. Idealnya perkampungan ini dapat menampung tenaga kerja masyarakat sekitar baik para pemuda maupun orang tua untuk dapat diberdayakan dalam hal ide, tenaga, wawasan, kemampuan, dan sebagainya dalam memajukan Perkampungan Budaya Betawi Setu Babakan, namun hal ini menjadi suatu ketertinggalan sumber daya manusianya jika tidak dapat menyesuaikan dalam pembangunan yang ada.

Selama ini Pemprov hanya memprioritaskan pembangunan fisik saja tanpa melihat bagaimana masyarakatnya yang tertinggal jauh pembangunan nonfisiknya, ditambah lagi masyarakat sekitar belum bisa menerima perubahan yang bergitu cepat yang hadir dalam kehidupannya. Pihak pengelola telah berusaha dengan berbagai pelatihan dan pemberdayaan untuk menjadikan masyarakat pemain di kampung mereka sendiri sehingga dapat mensejahterakan dirinya sendiri, tetapi nyatanya mental masyarakat belum siap menerimanya walaupun kampung mereka sudah berubah tidak seperti kampung mereka yang dahulu.

Jika dahulu mayoritas penduduk merupakan orang Betawi, namun saat ini masyarakat Betawi hanya tinggal $60 \%$ sedangkan sisanya $40 \%$ kaum pendatang. Munculnya kaum pendatang dari berbagai daerah di tanah air yang datang ke ibukota Jakarta khususnya di wilayah Perkampungan Budaya Betawi Setu Babakan menjadi suatu permasalahan ketika mereka lebih menonjol dibandingkan masyarakat sekitar yang semakin tertinggal baik dari segi ekonomi, pendidikan, jabatan, dan sebagainya. Selain itu keberadaan para pendatang dikhawatirkan memberikan dampak punahnya budaya Betawi, sebagaimana yang diungkapkan oleh Putri (2016: 1) bahwa budaya Betawi semakin terpinggirkan karena urbanisasi kota Jakarta yang berlebihan, penduduk urban yang telah berketurunan hanya mengajarkan nilai-nilai moral dari suku asal mereka tanpa mengenalkan budaya dimana mereka tempati. Berdasarkan masalah tersebut maka bukan tidak mungkin hal ini menjadi titik awal akan punahnya budaya lokal Jakarta Betawi.

Timbul suatu permasalahan berikutnya ketika kaum pendatang membawa budaya mereka ke kampung Betawi sehingga terjadi benturan budaya antara budaya setempat dengan budaya yang dibawa oleh pendatang, misalnya dalam acara pernikahan mereka menggunakan adat tradisi budaya mereka walaupun telah disosialisasikan bahwa setiap acara di area Perkampungan Budaya Betawi Setu Babakan maka harus bernuansa Betawi namun permasalahannya tidak semua penduduk orang Betawi sehingga penduduk dari daerah lain akan menyajikan budaya dari asalnya untuk menjamu tamu undangan mereka. 
Memang itu hak mereka untuk menyajikan kesenian dari daerah mereka, namun di masyarakat timbul suatu persepsi karena menganggap ini kampung Betawi seharusnya mereka menyajikan budaya Betawi, bagaimana sudut pandangan wisatawan jika mereka melihat di kampung Betawi adanya campur sari atau wayang golek yang bukan budaya Betawi, banyak hal lainnya yang menjadi benturan budaya bagi masyarakat pendatang Sebagaimana yang diungkapkan oleh Octaviani (2007: 86) bahwa adanya percampuran masyarakat di suatu tempat menimbulkan benturan budaya.

Selain itu, budaya Betawi tidak bisa dipaksakan oleh kaum pendatang misalnya dalam hal acara pindah rumah, jika orang Betawi biasanya mengadakan syukuran atau selamatan rumah baru tetapi karena kebanyakan yang pindah kekampung ini orang-orang pendatang yang belum tentu mereka mau melakukan tradisi tersebut, apalagi jika mereka pindah ke rumah bertingkat tidak akan mungkin mau merenovasi rumah mereka dengan nuansa Betawi atau melakukan berbagai tradisi Betawi, untuk sekedar bersosialisasi saja kebanyakan dari mereka tidak mau karena status sosial yang berbeda. Memang tidak bisa memaksakan budaya asli penduduk setempat kepada pendatang sekalipun itu Pemprov sendiri yang memiliki kekuasaan penuh dan tidak bisa memastikan sampai kapan mereka mau merenovasi rumah mereka dengan nuansa Betawi.

Keberadaan Perkampungan Budaya Betawi Setu Babakan yang sangat unik di tengah kota Jakarta menjadi daya tarik pengunjung untuk mengunjunginya. Ketika kondisi fisik Perkampungan Budaya Betawi Setu Babakan yang sudah maju pembangunannya, tetapi kondisi masyarakatnya yang masih belum meninggalkan kebiasaan lama, hal ini menjadi sebuah ketertinggalan seperti yang terjadi pada pedagang di Perkampungan Budaya Betawi Setu Babakan yang menjamu wisatawan dengan menggunakan pakaian yang bukan cirri khas Betawi. Padahal jika para pedagang menggunakan pakaian khas Betawi misalnya batik Betawi, baju pangsi, baju abang none akan terlihat lebih baik dan lebih sopan. Selain dapat mengenalkan pakaian Betawi kepada wisatawan, para pedagang juga dapat melestarikan pakaian Betawi yang sudah jarang digunakan sehingga dari situlah muncul identitas karakter budaya Betawinya.

Masyarakat lokal saat ini mulai terbiasa dengan kehadiran wisatawan yang sering keliling ke kampung mereka. Maka dari itu warga dituntut untuk menjaga lingkungan sekitar dengan tidak membuang sampah sembarangan, menyapa wisatawan yang berkeliling ke rumah mereka apalagi jika ada wisatawan yang tersesat atau ingin bertemu dengan tokoh di Perkampungan Budaya Betawi Setu Babakan maka warga wajib memberikan informasi, termasuk juga melakukan penataan terhadap kampung mereka agar terlihat indah dan nyaman, dan sebagainya.Tata aturan tersebut tidak dalam bentuk tulisan namun sebagai masyarakat Perkampungan Budaya Betawi 
Setu Babakan harus memiliki kesadaran bahwa tempat mereka tinggali terdapat kampung wisata budaya maka dari itu tata kelakuan atau perilaku mereka harus sesuai dengan nilai budaya dan nilai-nilai yang berlaku di masyarakat. Masyarakat tidak boleh acuh dengan kehadiran wisatawan mereka juga harus memberikan informasi kepada wisatawan tentang kampung mereka.

Adanya tempat wisata di Perkampungan Setu Babakan memberikan dampak positif maupun negatif bagi masyarakat sekitar. Sebagaimana yang diungkapkan dalam penelitian Qomarudin (2013: 45) yaitu "keberadaan desa wisata memberikan manfaat bagi masyarakat diantaranya peningkatan pendapatan, semakin majunya pola pikir masyarakat, meningkatnya kesadaran untuk melindungi ekosistem, sedangkan dampak negatif yaitu materialistis dan individualistik, semakin tingginya tingkat pencemaran, pembangunan tidak dirasakan oleh semua lapisan masyarakat". Dengan adanya tempat pariwisata di sebuah kawasan pastilah akan menimbulkan perubahan bagi masyarakat sekitar termasuk yang terjadi pada masyarakat Perkampungan Budaya Betawi Setu Babakan, ada yang berdampak negatif maupun positif seperti yang telah di paparkan di atas. Sekarang permasalahannya bagaimana caranya untuk menyesuaikan dengan keberadaan Perkampungan Budaya Betawi Setu Babakan Setu Babakan bagi kehidupan masyarakat sekitar agar memberikan manfaat dampak positif bagi masyarakat.
Masalah mengenai ketertinggalan budaya tersebut telah diteliti oleh Gunawan (2015) yang menemukan bahwa perubahan sosial budayamenimbulkan dampak positif manakala masyarakat dapat memanfaatkan dengan baik berbagai macam objek pariwisata dan sarana pendukung lainnya, sebaliknya akan menimbulkan dampak negatif bagi masyarakat yang tidak dapat memanfaatkan adanya objek pariwisata tersebut dan menyebabkan ketertinggalan budaya. Berdasarkan penelitian tersebut dapat menjadi suatu pelajaran berharga agar masyarakat Perkampungan Budaya Betawi Setu Babakan dapat memanfaatkan keberadaan Perkampungan Budaya Betawi Setu Babakan sehingga dapat meningkatkan kesejahteraan warga sekitar dengan pemberdayaan dan pelatihan dibidang ekonomi maupun pariwisata, mereka juga mau melestarikan kesenian budaya Betawi, memperkenalkan tradisi yang mereka miliki kepada para wisatawan, dan sebagainya. Intinya masyarakat harus dapat menjadi pemain di kampung mereka sendiri bukan penonton yang hanya menyaksikan kampung mereka semakin berubah tanpa berbuat apa-apa.

Berdasarkan temuan peneliti, jika pembangunan Perkampungan Budaya Betawi Setu Babakan hanya berorientasi pada pembangunan fisik belaka maka akan terjadi disfungsional terhadap masyarakat, karena masyarakat setempat tidak mampu beradaptasi dengan lingkungan kampung mereka sebagai kampung wisata sehingga terjadi cultural lag. Pembangunan fisik selama 16 tahun 
(2000-2016) yang semakin progresif tidak diimbangi dengan kondisi masyarakat yang semakin tertinggal dari pembangunan. Sebagaimana yang diungkapkan oleh Merton (dalam Raho, 2007: 63) yaitu "ada dua pemikiran Merton mengenai disfungsi: sesuatu bisa saja mempunyai akibat yang tidak berfungsi karena adaptasi atau penyesuaian diri dengan sistem,akibat kepentingan orang yang terlibat berbeda, oleh karena itu Sosiolog bertanya berfungsi atau tidak berfungsi untuk siapa?"

Walaupun di awal konsep pembangunan sangat menjunjung tinggi keberadaan masyarakat namun fakta sosial tidak bisa dipungkiri bahwa masyarakat semakin dinamis dalam menghadapi perubahan karena tidak ada yang bisa menjamin bahwa masyarakat selalu beradaptasi menyesuaikan diri dengan perubahan sesuai dengan pembangunan. Apalagi jika banyak kepentingan antara golongan satu dengan yang lainnya yang tidak sejalan sehingga timbul permasalahan pembangunan yang ada hanya dapat dinikmati oleh oknum tertentu saja sedangkan masyarakat menganggap tidak berfungsi apa-apa bagi kehidupannya, padahal jika dimanfaatkan dengan baik banyak potensi yang dapat masyarakat gali dari keberadaan Perkampungan Budaya Betawi Setu Babakan.

Upaya mengatasi ketertinggalan budaya pada masyarakat Perkampungan Budaya Betawi Setu Babakan membutuhkan proses yang panjang dan memerlukan peran dari berbagai pihak untuk menyelesaikan persoalan tersebut mulai dari masyarakat pribumi maupun pendatang, tokoh masyarakat, pihak pengelola yaitu UPK (Unit Pengelola Kawasan) Perkampungan Budaya Betawi Setu Babakan, Pemprov DKI Jakarta, dan berbagai pihak lainnya. Konsep awal pembangunan Perkampungan Budaya Betawi Setu Babakan lahir atas inisiatif masyarakat Betawi sendiri yang merasa penting mempertahankan eksistensi budaya mereka ditengah kemajuan zaman, sehingga akhirnya ide tersebut di respon oleh pemerintah daerah yang berfungsi memfasilitasi berbagai pembangunan yang ada, sedangkan yang menjalani kegiatan yang ada di Perkampungan Budaya Betawi Setu Babakan diserahkan kepada masyarakat dengan kata lain terdapat konsep pembangunan dari masyarakat, oleh masyarakat, dan untuk masyarakat. Maka mengejar ketertinggalan tersebut caranya mengembalikan pembangunan pada tujuan semula yaitu pembangunan berbasis masyarakat.

Masyarakat Perkampungan Budaya Betawi sebenarnya merupakan masyarakat yang modern tetapi belum tentu modern juga alam pikirannya. Pola pikirmasyarakat bisa saja bersifat tradisional walaupun mereka menganggap diri mereka orang modern. Menurut Soekanto (2010: 298) menyatakan bahwa "alam pikiran masyarakat yang modern ditandai dengan beberapa hal misalnya sifat yang terbuka terhadap pengalaman baru serta terbuka bagi perubahan dan pembaharuan". Masyarakat tidak hanya memiliki keterbukaan tentang pembangunan fisik Perkampungan Budaya 
Betawi Setu Babakan tetapi secara jiwa mereka juga terbuka menerima pembaharuan yang ada. Masyarakat mau berfikir jangka panjang maka dari itu mereka harus melakukan perencanaan untuk masa yang akan datang. Masyarakat harus berfikir luas tidak hanya memikirkan apa yang ada disekelilingnya tetapi juga berbagai hal yang ada di luar sehingga luas pemikirannya atau out the box.

Mindset masyarakat yang tertinggal harus dirubah agar dapat menjadi manusia yang modern alam pikirannya menerima pembaharuan agar dapat memanfaatkan Sumber Daya Alam (SDA) yang ada dengan Sumber Daya Manusia (SDM) yang harus berkualitas. Mindset masyarakat harus diarahkan bahwa Perkampungan Budaya Betawi Setu Babakan dapat menjadi sumber kehidupan mereka dapat memberikan kesejahteraan bagi kehidupan masyarakat dan memberikan lapangan pekerjaan yang baru bagi masyarakat sekitar, oleh karena itu masyarakatlah yang harus berperan aktif dalam Perkampungan Budaya Betawi Setu Babakan.

Mindset hidup pasrah pada nasib tidak bisa mengembangkan diri atau malas bekerja dapat dirubah dengan kemauan tekad yang kuat untuk bekerjakeras merubah nasib.Tugas bersama Pemprov DKI Jakarta, pihak pengelola, tokoh masyarakat bersama-sama untuk memberikan bimbingan dan arahan agar masyarakat memiliki alam pikiran sebagai masyarakat modern yang berpikir maju, terbuka dengan pembaharuan, menyalurkan ide, gagasan, kreativitas yang mereka miliki untuk memajukan Perkampungan Budaya Betawi Setu Babakan melalui rapat terbuka, sosialisasi ke masyarakat, melalui majlis ta'lim, dan sebagainya.

Ketertinggalan terjadi akibat ketidakmampuan masyarakat menyesuaikan diri dengan kondisi lingkungan sekitar mereka yang telah berubah. Oleh karena itu, sebagai upaya mengatasi ketertinggalan perlu adanya penyesuaian masyarakat terhadap Perkampungan Budaya Betawi Setu Babakan, sebagaimana yang dikemukakan Ogburn (Martono, 2012: 287) berpendapat "teori cultural lag ada dua jenis penyesuaian sosial yaitu penyesuaian antara berbagai bagian kebudayaan, serta penyesuaian antara kebudayaan dan manusia". Perlu adanya penyesuaian untuk semua aspek baik segala unsur budaya yang ada di Perkampungan Budaya Betawi Setu Babakan maupun dengan manusianya untuk dapat bersama-sama mewujudkan pembangunan Perkampungan Budaya Betawi Setu Babakan sesuai dengan perencanaan master plan Perkampungan Budaya Betawi Setu Babakan.

Pembangunan fisik tidak akan terlaksana tanpa didukung dengan pembangunan nonfisiknya, begitupun sebaliknya. Sehingga masyarakat harus menjadi agent of change dalam pembangunan Perkampungan Budaya Betawi Setu Babakan, sebagaimana dijelaskan oleh Melati (2013: 295) bahwa telah terjadi perubahan sosial pada masyarakat desa wisata dengan pengaruh utama yaitu pengaruh masyarakat itu 
sendiri yang ingin melakukan perubahan. Oleh karena itu harus timbul kesadaran bagi masyarakat untuk merubah hidupnya kearah yang lebih baik.

Pembangunan Perkampungan Budaya Betawi Setu Babakan tidak akan berjalan tanpa adanya dukungan penuh dari masyarakat sekitar dan Pemprov DKI Jakarta. Perubahan yang ada di Perkampungan Budaya Betawi dirasakan masyarakat sangatlah beragam, ada yang menganggap adanya perubahan sejak adanya Perkampungan Budaya Betawi Setu Babakan terutama peningkatkan kesejahteraan mereka dibidang ekonomi, dan ada juga masyarakat yang menganggap tidak ada perubahan apa-apa karena mereka tidak berperan dalam pembangunan Perkampungan Budaya Betawi Setu Babakan. Namun apapun respon masyarakat dalam pembangunan Perkampungan Budaya Betawi Setu, nyatanya pembangunan Perkampungan Budaya Betawi Setu Babakan tidak akan terjadi sampai dengan saat ini tanpa adanya partisipasi penuh dari masyarakat sekitar, oleh karena itu perlu adanya langkah nyata masyarakat untuk memajukan Perkampungan Budaya Betawi Setu Babakan.

Hal tersebut sesuai dengan penelitian yang pernah dilakukan oleh Lumintang (2015) yang menemukan bahwa keikutsertaan masyarakat dalam pembangunan di desa wisata ialah tanggung jawab sebagai masyarakat untuk mengadakan perubahan sesuai dengan kebutuhan, ada masyarakat yang sangat diuntungkan karena perbaikan taraf hidupnya dalam ekonomi; dan ada yang menyatakan tidak terjadi perubahan karena mereka tidak mau berusaha atau apatis terhadap pembangunan. Pembangunan merupakan beban dan tanggung jawab bersama pemerintah dan masyarakatnya. Sehingga masyarakat menyadari bahwa tanpa partisipasi dan swadaya masyarakat dalam pembangunan maka perubahan untuk kemajuan sulit akan tercapai.

Berbagai pihak yang terlibat dalam pembangunan Perkampungan Budaya Betawi Setu Babakan baik Pemprov DKI Jakarta, pihak pengelola, tokoh masyarakat, beserta masyarakat pribumi maupun pendatang menjalin komunikasi yang baik sehingga dapat bekerjasama untuk menjadikan Perkampungan Budaya Betawi Setu Babakan sebagai cagar budaya yang wajib dilindungi bersama baik dari segi fisik maupun nonfisiknya. Tentunya untuk menjalin sebuah komitmen perlu adanya aturan-aturan yang menjadi keputusan bersama dan dipatuhi bersamasama, sehingga semua permasalahan yang ada di Perkampungan Budaya Betawi Setu Babakan dapat diselesaikan bersama-sama demi kemaslahatan semua pihak, termasuk permasalahan yang terjadi di masyarakat mulai dari jual beli lahan perluasan Perkampungan Budaya Betawi Setu Babakan, masalah masyarakat yang masih menganggur, masalah kurangnya partisipasi masyarakat, dan berbagai pelanggaran-pelanggaran yang terjadi di perkampungan ini.

Berbagai ketertinggalan tersebut akan semakin cepat berubah jika ada kesadaran dari masyarakat. Kerelaan hati masyarakat mengejar ketertinggalan mereka merubah 
mind set mereka yang tidak selaras dengan pembangunan agar dapat menyesuaikan dengan pembangunan yang ada. Kesadaran berbudaya tidak untuk dipaksa dari atas atau bukan semata-mata menunggu perintah dari Pemda bersifat top down. Jika otoritas pemerintah yang besar terhadap kampung wisata yang berakibat pada kepunahan seperti apa yang disampaikan Octaviani (2007: 86) bahwa punahnya kampung wisata akibat adat istiadat yang tidak lagi dijalankan, kampung wisata telah diambil alih oleh sistem pemerintahan. Oleh karena itu, segala kebijakan harus bersifat bottom up berasal dari masyarakat karena masyarakat sendirilah yang mengerti apa yang dibutuhkan oleh mereka.

Salah satu cara mengejar ketertinggalan dengan mengedepankan pendidikan bagi masyarakat sekitar, karena tanpa disadari bahwa masyarakat yang cerdas dapat terhindar dari ketertinggalan budaya. Merubah pola pikirmasyarakat melalui pendidikan baik formal, nonformal, maupun informal merupakan salah satu langkah mengejar ketertinggalan, karena dengan pendidikan masyarakat akan semakin luas dan terbuka pemikirannya. Pendidikan membuat masyarakat lebih dapat berfikir secara ilmiah, logis, terencana, terarah, sehingga terhindar dari ketertinggalan. Masyarakat yang berpendidikan akan mau dilatih dan diberdayakan karena mereka mau belajar untuk memanfaatkan sumber daya alam yang ada dengan sumber daya manusia yang mereka miliki bukan hidup sekedar pasrah pada nasib tidak bisa mengembangkan diri atau malas. Inilah hal yang perlu diaplikasikan pada masyarakat Perkampungan Budaya Betawi Setu Babakan agar mau merubah hidupnya kearah yang lebih baik berorientasi masa depan.

Budaya Betawi harus dikenalkan sejak dini tidak hanya bagi masyarakat setempat namun juga masyarakat luas sehingga penyesuaian kurikulum harus dilakukan untuk mewajibkan pelajar dari tingkat taman kanak-kanak sampai perguruan tinggi untuk mempelajari budaya Betawi dalam mata pelajaran muatan lokal budaya Betawi DKI Jakarta. Para pelajar diwajibkan mengunjungi Perkampungan Budaya Betawi Setu Babakan untuk menumbuhkan kesadaran akan berbudaya kepada generasi muda seperti belajar tarian budaya Betawi, pembuatan cinderamata gantungan kunci ondelondel, membatik Betawi, melihat pembuatan makanan minuman khas Betawi seperi dodol, bir pletok, dan sebagainya.

Hal tersebut selaras dengan penelitian yang dilakukan oleh Sudrajat (2014: 189) yang menemukan akan pentingnya bagi siswa untuk menerapkan nilai-nilai budaya lokal dalam kehidupan sehari-hari sehingga siswa memiliki kesadaran budaya lokal sebagai penopang budaya nasional. Berdasarkan penelitian tersebut kesadaran akan budaya lokal yang dimiliki setiap siswa dapat menjadi penunjang budaya nasional, sehingga siswa memiliki kecintaan terhadap budaya bangsa dan tidak mudah untuk terjerumus dalam perubahan zaman dalam arus budaya luar yang negatif. 
Pendidikan juga sebagai media yang sangat penting untuk menyiapkan generasi muda masyarakat Perkampungan Budaya Betawi Setu Babakan agar mendapatkan bekal ilmu pengetahuan tentang pariwisata sehingga masyarakat dapat menjadi tour guide dengan kemampuan bahasa asing yang mempuni sehingga informasi tentang Perkampungan Budaya Betawi Setu Babakan baik secara fisik maupun kultural dapat disampaikan kepada wisatawan. Kedepan akan adanya lembaga pendidikan di Perkampungan Budaya Betawi Setu Babakan yaitu Sekolah Menengah Kejuruan (SMK) Kesenian Betawi, diharapkan sekolah ini menjadi suatu wadah bagi generasi muda mempelajari kebudayaan Betawi.

Selain itu diharapkan adanya beasiswa bagi anak-anak Betawi yang berprestasi sampai pendidikan tinggi sehingga dengan ilmu yang mereka miliki dapat membawa perubahan hidup masyarakat maupun untuk kemajuan Perkampungan Budaya Betawi Setu Babakan. Keterbatasan pendidikan masyarakat lokal dan ketidakmampuan memberikan informasi kepada wisatawan menjadi permasalahan di Perkampungan Budaya Betawi Setu Babakan, maka dengan jalan pendidikan untuk masyarakat sekitar diharapkan dapat menciptakan masyarakat yang dapat memanfaatkan berbagai potensi di Perkampungan Budaya Betawi Setu Babakan sehingga Perkampungan Budaya Betawi Setu Babakan dapat memiliki nilai jual yang tinggi bagi wisatawan lokal maupun mancanegara.
Bagi masyarakat sekitar perlu adanya langkah nyata dalam mempersiapkan kesiapan mental masyarakat dalam menerima berbagai perubahan dengan cara melakukan berbagai pelatihan dan pemberdayaan masyarakat yang berlangsung secara continu di berbagai bidang pariwisata dengan mengangkat potensi lokal yang ada di Perkampungan Budaya Betawi Setu Babakan. Masyarakat dibekali dengan keterampilan yang mereka dapat kembangkan di Perkampungan Budaya Betawi Setu Babakan karena bagaimanapun masyarakat harus berperan aktif dalam memajukan kampung Betawi yang ada di daerahnya. Misalnya terampil menyediakan apa yang dibutuhkan wisatawan, terampil dalam menyuguhkan makanan dan minuman Betawi, keterampilan dalam pembuatan cinderamata khas Betawi seperti ondelondel, terampil dalam memberikan informasi dengan para wisatawan, terampil dalam berkesenian budaya Betawi, dan sebagainya.

Masyarakat harus dibekali dengan pedoman dalam menjamu tamu seperti bertatakrama yang baik, sopan santun, berbudi pekerti, menyambut wisatawan dengan ramah, mejamu wisatawan dengan baik, dan sebagainya. Masyarakat Betawi berpedoman pada nilai-nilai luhur budaya Betawi yang berciri khas Islami. Oleh karena itu, perlu pembinaan sikap atau tata krama masyarakat sekitar secara terus menerus sehingga masyarakat dapat memiliki sikap baik dan beradab. 
Perkampungan Budaya Betawi Setu Babakan menjadi wadah untuk mengangkat potensi nilai-nilai lokal masyarakat Betawi sebagai upaya mengembangkan glokalisasi dengan memperkenalkan budaya Betawi pada era globalisasi. Hal ini selaras dengan pendapat Yuwono (2016: 73) yaitu "pembangunan kota Jakarta harus tercipta suatu keseimbangan antara pembangunan fisik dengan pembangunan manusia dengan mengangkat potensi nilai-nilai lokal sebagai upaya mengembangkan konsepglokalisasi”. Mempertahankan kampung di tengah kota seperti di Perkampungan Budaya Betawi Setu Babakan yang memiliki potensi sejarah dan budaya dalam rangka melestarikan nilai-nilai sejarah dan budaya di perkampungan tersebut.

Eksistensi perkampungan Betawi ini harus tetap terjaga sampai nanti dengan berbagai cara dilakukan agar ketertinggalan tersebut tidak terjadi lagi dan awal dari kebangkitan budaya Betawi pada era globalisasi ini. Pembangunan Perkampungan Budaya Betawi Setu Babakan harus selaras pembangunan fisik dan nonfisiknya sehingga tercipta keseimbangan diantara keduanya. Pembangunan Perkampungan Budaya Betawi Setu Babakan diharapkan sebagai langkah untuk mengangkat potensi nilainilai lokal Betawi sebagai upaya mengembangkan konsep glokalisasi yaitu dengan memperkenalkan budaya Betawi dimata dunia.

Mengenalkan budaya Betawi misalnya makanan dan minuman tradisionalnya, mengenalkan adat tradisi masyarakatnya yang masih dijalani sampai dengan saat ini, mengenalkan berbagai hasil kerajinan masyarakatnya, mengenalkan rumah adat milik masyarakat, menampilkan kesenian Betawi, mengenalkan kearifan lokal, masyarakat yang berbudi pekerti, masyarakat yang berbudaya, dengan disertai sarana dan fasilitas pariwisata yang maju. Hal ini menjadi sebuah modal dalam mengenalkan budaya Betawi di mata dunia yang menjadi keunikan budaya Betawi sebagai budaya asli dari kota Jakarta ditengah kemajuan zaman modern.

\section{KESIMPULAN}

Perkampungan Budaya Betawi Setu Babakan merupakan perkampungan rekacipta yang dilakukan oleh Pemerintah Provinsi DKI Jakarta sebagai upaya mempertahankan kebudayaan lokal asli Jakarta pada era globalisasi. Berbagai pembangunan dilakukan mulai dari pembangunan fisik maupun nonfisik, namun sayangnya terjadi permasalahan ketika pembangunan fisik lebih progresif dibandingkan pembangunan nonfisik masyarakatnya. Melalui teori cultural lag karya Ougburn ini, peneliti memberikan gambaran mengenai ketertinggalan yang terjadi pada kehidupan masyarakat Perkampungan Budaya Betawi Setu Babakan.

Pada awal pembangunan masyarakat sangat antusias secara langsung dalam berbagai kegiatan seperti kesenian, perekonomian, dan kegiatan masyarakat Betawi di Perkampungan Budaya Betawi Setu Babakan, namun seiring berjalannya 
waktu terdapat suatu masa ketika masyarakat merasa telah jenuh bahkan merasa tidak dipedulikan lagi oleh pihak pengelola, apalagi ketika segala kebijakan berasal dari pusat yang bersifat top down sehingga partisipasi masyarakat di Perkampungan Budaya Betawi Setu Babakan saat ini mulai menurun.

Perubahan yang terjadi pada Perkampungan Budaya Betawi Setu Babakan menimbulkan dampak positif manakala masyarakat dapat memanfaatkan dengan baik berbagai macam objek pariwisata dan sarana pendukung lainnya, sebaliknya akan menimbulkan dampak negatif bagi masyarakat yang tidak dapat memanfaatkan sehingga menyebabkan ketertinggalan budaya atau cultural lag.

Selama ini pembangunan Perkampungan Budaya Betawi Setu Babakan hanya berorientasi pada pembangunan fisik belaka maka pembangunan tersebut disfungsional bagi masyarakat.

Upaya mengatasi ketertinggalan dilakukan dengan cara melakukan kebijakan secara bottom up dengan mengembalikan pembangunan yang berbasis masyarakat karena masyarakatlah sebagai agent of change atas jasa masyarakat Betawilah perkampungan ini terwujud. Mindset masyarakat yang tertinggal harus dirubah menjadi masyarakat modern yang berpikir maju, terbuka dengan pembaharuan, menyalurkan ide, gagasan, kreativitas yang mereka miliki, agar terwujud tujuan sesuai dengan perencanaan master plan Perkampungan Budaya Betawi Setu Babakan.
Cara mengejar ketertinggalan lainnya dengan mengedepankan pendidikan bagi masyarakat sekitar baik pendidikan formal, nonformal, maupun informal. Perkampungan Budaya Betawi Setu Babakan menjadi wadah untuk mengangkat potensi nilai-nilai lokal masyarakat Betawi sebagai upaya mengembangkan glokalisasi dengan memperkenalkan budaya Betawi pada era globalisasi. Eksistensi perkampungan Betawi ini harus tetap terjaga sampai nanti dengan berbagai cara dilakukan agar ketertinggalan tersebut tidak terjadi lagi dan awal dari kebangkitan budaya Betawi pada era globalisasi.

\section{REFERENSI}

Alwasilah, C. (2015). Pokoknya Studi Kasus Pendekatan Kualitatif. Bandung: Kiblat Buku Utama.

Brinkman, R. \& Brinkman, J. (2006). Cultural Lag: In the Tradition of Veblenian Economics. Journal Of Economic Issues Vol. 40 No. 4 h. 1009-1028.

Chaer, A. (2015). Betawi Tempo Doeloe Menelusuri Sejarah Kebudayaan Betawi. Depok: Masup Jakarta.

Creswell, J. W. (2014). Research design pendekatan kualitatif, kuantitatif, dan mixed (terjemahan Achmad Fawaid). Yogyakarta: Pustaka Pelajar.

Gunawan, H. (2015). Analisis Perubahan Sosial Budaya Masyarakat Desa Cihideung sebagai Desa Wisata. Jurnal Sosietas Vol. 5 No.2.

Hatu, R. (2011). Perubahan Sosial Kultural Masyarakat Pedesaan. Jurnal Inovasi Vol. 8 No. 4 h. 1-11. 
Hidayat, S. (2015). Pengaruh Keberadaan Kampung Inggris Terhadap Guna Lahan dan Sosial Ekonomi Masyarakat Di Desa Tulung Rejo dan Desa Palem Kabupaten Kediri. Jurnal Tata Kota Dan Daerah Vol. 3 No. 1 h. 11-18.

Kaesthi, E. (2014). Perubahan sosial budaya masyarakat di desa wisata Karangbanjar kabupaten Purbalingga. Jurnal Solidarity Vol. 3 No. 1 h. 56-61.

Lumintang, J. (2015). Pengaruh Perubahan Sosial Terhadap Kemajuan Pembangunan Masyarakat Di Desa Tara-Tara.Jurnal Acta Diurna Vol. 4 No. 2.

Martono, N. (2012). Sosiologi Perubahan Sosial Perspektif Klasik, Modern, Postmodern dan Postkolonial. Jakarta: Grafindo Persada.

Marzali, A. (2009). Antropologi dan Pembangunan Indonesia. Jakarta: Kencana.

Melati, F. (2013). Dinamika Perubahan Sosial Dan Budaya di Desa Kendalsari, Kecamatan Sumobito, Kabupaten Jombang. Jurnal Antro Unair Vol. 2 No. 1 h. 291-297.

Moechtar, M. (2012). Identifikasi Pola Permukiman Tradisional Kampung Budaya Betawi Setu Babakan, Kelurahan Srengseng Sawah, Kecamatan Jagakarsa, Kota Administrasi Jakarta Selatan, Provinsi DKI Jakarta. E-Jurnal Agroekoteknologi Tropika Vol. 1 No.2. h. 135-143.

Moleong, L. J. (2012). Metode Penelitian Kualitatif Edisi Revisi. Bandung: Remaja Rosdakarya.

Mubah, A. (2011). Strategi Meningkatkan Daya Tahan Budaya Lokal dalam Menghadapi Arus Globalisasi. Jurnal Fisip Unair Vol. 24 No.31 h. 302-308.
Munandar, A. (1996). Proses Pengkotaan dan Perubahan Sosial Ekonomi Masyarakat Pinggiran Kota Jakarta. Tesis. Fakultas Ilmu Sosial dan Ilmu Politik Universitas Indonesia.

Octaviani, D. (2007). Perubahan Sosial Budaya Orang Melayu (Studi Kasus di Kampung Terjun dan Pekan Labuhan). Tesis. Program Studi Antropologi Sosial Universitas Negeri Medan.

Oktaviyanti, S. (2013). Pariwisata. Jurnal Nasional Pariwisata Vol. 5 No.3. h. 154-167.

Parwitaningsih. (2003). Identitas Orang Betawi Dalam Komunitas Heterogen (Studi di Kampung Baru, Kelurahan Cirendeu, Tangerang). Tesis. Fakultas Ilmu Sosial dan Ilmu Politik Universitas Indonesia.

Peraturan Gubernur Provinsi DKI Jakarta No. 3 Tahun 2005 tentang Penetapan Perkampungan Budaya Betawi di Kelurahan Srengseng Sawah, Kecamatan Jagakarsa, Jakarta Selatan.

Putri, F. \& Maharani, Y. 2016. Betawi Culture And Nature Conservation Through Ecotourism Education. Jurnal Tingkat Sarjana Bidang Senirupa Dan Desain No.1 h. 1-6.

Qomarudin. (2013). Perubahan Sosial dan Peran Masyarakat dalam Pengembangan Kawasan Wisata Kepulauan Karimun Jawa. Journal of Educational Social Studies VoL. 2 No.1 h. 41-46.

Raho, B. (2007). Teori Sosiologi Modern. Jakarta: Prestasi Pustaka.

Setiadi, E. M. \& Kolip, U. (2011). Pengantar Sosiologi Pemahaman Fakta dan Gejala Permasalahan Sosial : Teori, Aplikasi, dan Pemecahnya. Jakarta: Kencana. 
Silalahi, U. (2010). Metode Penelitian Sosial. Bandung: Refika Aditama.

Soekanto, S. (2010). Sosiologi Suatu Pengantar. Jakarta: Rajawali Pers.

Steinberg, F. (2007). Jakarta: Environmental problems and sustainability. Jurnal Habitat International Vol. 31 h. 354-365.

Sudrajat, A. 2014. Nilai-Nilai Budaya Gotong Royong Etnik Betawi Sebagai Sumber Pembelajaran IPS (Penelitian Verifikatif Kualitatif Di Perkampungan Budaya Betawi Setu Babakan Kelurahan Srengseng Sawah Kecamatan Jagakarsa Jakarta Selatan). Disertasi. Program Studi Pendidikan Ilmu Pengetahuan Sosial Universitas Pendidikan Indonesia.

Surat Keputusan Gubernur No. 92 Tahun 2000 tentang Penataan Lingkungan Perkampungan Budaya Betawi di
Kelurahan Srengseng Sawah, Kecamatan Jagakarsa, Jakarta Selatan.

Waha, R. (2016). Pengaruh Objek Wisata Tasikria Terhadap Masyarakat Di Desa Mokupa Kecamatan Tombariri. ASE Vol. 12 No. 1 h. 1-18.

Wardiningsih, S. (2005). Rencana Pengelolaan Lanskap Perkampungan Budaya Betawi Di Setu Babakan Srengseng Sawah Kecamatan Jagakarsa Jakarta Selatan. Tesis. Program Studi Arsitektur Lanskap Institut Pertanian Bogor.

Yuwono, S. (2016). Mempertahankan Keberadaan Kampung di Tengah-Tengah Kawasan Modern Jakarta. Jurnal Arsitektur NALARs Vol.15 No. 1 h. 73-80. 
[ halaman ini sengaja dikosongkan ] 